Article

\title{
Increase of Salt Tolerance in Carbon-Starved Cells of Rhodopseudomonas palustris Depending on Photosynthesis or Respiration
}

\author{
Sawa Wasai ${ }^{\dagger}$, Nanako Kanno, Katsumi Matsuura and Shin Haruta * \\ Department of Biological Sciences, Tokyo Metropolitan University, 1-1 Minami-Osawa, Hachioji, Tokyo 192-0397, \\ Japan; arai.sawa@ige.tohoku.ac.jp (S.W.); n_kanno@tmu.ac.jp (N.K.); matsuura-katsumi@tmu.ac.jp (K.M.) \\ * Correspondence: sharuta@tmu.ac.jp; Tel.: +81-42-677-2580 \\ + Present address: Graduate School of Life Sciences, Tohoku University, Sendai 980-8577, Japan.
}

Received: 1 December 2017; Accepted: 3 January 2018; Published: 6 January 2018

\begin{abstract}
Bacteria in natural environments are frequently exposed to nutrient starvation and survive against environmental stresses under non-growing conditions. In order to determine the energetic influence on survivability during starvation, changes in salt tolerance were investigated using the purple photosynthetic bacterium Rhodopseudomonas palustris after carbon starvation under photosynthetic conditions in comparison with anaerobic and aerobic dark conditions. Tolerance to a treatment with high concentration of salt $(2.5 \mathrm{M} \mathrm{NaCl}$ for $1 \mathrm{~h})$ was largely increased after starvation under anaerobically light and aerobically dark conditions. The starved cells under the conditions of photosynthesis or aerobic respiration contained high levels of cellular ATP, but starvation under the anaerobic dark conditions resulted in a decrease of cellular ATP contents. To observe the large increase of the salt tolerance, incubation of starved cells for more than $18 \mathrm{~h}$ under illumination was needed. These results suggest that the ATP-dependent rearrangement of cells induced salt tolerance.
\end{abstract}

Keywords: carbon starvation; salt stress tolerance; cellular energy; purple photosynthetic bacteria

\section{Introduction}

Bacteria are often exposed to nutrient-depleted conditions in natural environments [1]. Bacterial functions and strategies for survival and distribution in nature are strongly related to nutrientdepleted conditions. Bacteria likely change their cellular metabolisms to adapt to nutrient-depleted conditions [2]. Bacterial behaviors under carbon-starved non-growing conditions have been studied extensively in Escherichia coli and other bacteria in human microbiota [3-8]. Recently, much attention has been paid to bacteria in natural environments as well [9]. As a pronounced cellular response to nutrient starvation, a cell size reduction has been observed [10-17]. Recently, Wu et al. reported the reduction of ATP levels in starved cells of mycobacteria [17]. Other studies reported that bacteria under starved conditions had increased tolerance against environmental stresses, e.g., salt, hyperosmotic pressure, desiccation, heat, and ultraviolet (UV) radiation $[3,16,18]$. Transcriptional factors responding to the starvation have also been extensively examined [19-22]. However, it is still unclear how cellular energy contributes to these starvation responses.

Purple photosynthetic bacteria are able to convert light energy to ATP by anoxygenic cyclic photophosphorylation. It has been reported that illumination prolongs the viability of purple photosynthetic bacteria [23-25]. In addition, Kanno et al. previously examined ATP contents in purple photosynthetic bacteria, Rhodopseudomonas palustris and Rhodospirillum rubrum, under carbon-starved conditions and reported that illumination largely affected the maintenance of cellular ATP contents under carbon-starved conditions [24]. These results suggest that cellular ATP is utilized to increase the survivability of the purple photosynthetic bacteria. In this study, we prepared carbon-starved cells 
of the purple photosynthetic bacterium R. palustris, which is widely distributed and metabolically versatile [26], and we investigated changes in salt tolerance after short-term starvation under photosynthetic conditions, as compared with anaerobic and aerobic dark conditions.

\section{Materials and Methods}

\subsection{Bacterial Growth and Preparation of Carbon-Starved Cells}

R. palustris ATCC BAA-98 (= CGA009) was obtained from the American Type Culture Collection. This bacterial strain was anaerobically pre-cultured under illumination at $30{ }^{\circ} \mathrm{C}$ in a carbon-rich medium [24]. To obtain carbon-starved cells, $1 \mathrm{~mL}$ of culture at the early stationary phase of growth was inoculated into $20 \mathrm{~mL}$ of a carbon-limited medium in 32-mL glass test tubes. The glass test tubes were sealed with butyl rubber stoppers and screw caps after replacing the gas phase with $\mathrm{N}_{2}$ gas. The carbon-limited medium contained $0.5 \mathrm{~g} / \mathrm{L}$ of disodium succinate hexahydrate as a sole carbon source as described previously [24]. The anaerobic culture was illuminated (tungsten lamp with a 750-nm longpass filter) at $30{ }^{\circ} \mathrm{C}$ and the growth stopped at an optical density of approximately 0.3 (Figure S1), although the optical density reached 1.0 in the carbon-rich medium, as reported previously [24]. We defined the exponentially growing cells approximately $2 \mathrm{~h}$ before growth termination as "growing cells". The cells that showed no further growth were defined as "starvation-initiated cells". The starvation-initiated cells were incubated for $24 \mathrm{~h}$ either in lighted or darkened conditions. In addition, the starvation-initiated cells were transferred into T-shaped test tubes equipped with a silicon plug (Silicosen, Shin-etsu Polymer, Tokyo, Japan) and were aerobically incubated with shaking at $120 \mathrm{rpm}$ in the dark.

\subsection{Cellular ATP Contents}

Cellular ATP contents were determined as follows: bacterial cells in $100 \mu \mathrm{L}$ of culture were collected by centrifugation after suspension in $900 \mu \mathrm{L}$ of pre-chilled $50 \mathrm{mM}$ HEPES buffer ( $\mathrm{pH}$ 7.0). The cells were suspended in $400 \mu \mathrm{L}$ of $0.1 \mathrm{M} \mathrm{HNO}_{3}$ and incubated on ice without illumination for $10 \mathrm{~min}$ to extract cellular ATP. Then, $500 \mu \mathrm{L}$ of $0.185 \mathrm{M}$ Tris were added and the samples were stored at $4{ }^{\circ} \mathrm{C}$ until measurement. The ATP concentration in the sample was measured using ATP Bioluminescence Assay Kit CLS II (Roche Diagnostics GmbH, Mannheim, Germany) and a microplate reader (infinite M200 PRO, Tecan, Seestrasse, Switzerland).

\subsection{Evaluation of Salt Stress Tolerance}

Salt stress tolerance was evaluated as follows: one $\mathrm{mL}$ of culture solution was added into $4 \mathrm{~mL}$ of the carbon-free medium supplemented with $\mathrm{NaCl}$ (final concentration, $2.5 \mathrm{M}$ ) in a 32-mL test tube that was sealed with a butyl rubber stopper and a screw cap after replacing the gas phase with $\mathrm{N}_{2}$ gas. The tubes were incubated for $1 \mathrm{~h}$ at $30^{\circ} \mathrm{C}$ in the dark. Viability was determined by colony counting using PYS (5.0 g polypeptone, $1.0 \mathrm{~g}$ yeast extract, $5.0 \mathrm{~g}$ sodium succinate, $1.0 \mathrm{~g}$ casamino acids, $1.0 \mathrm{~g}$ $\left(\mathrm{NH}_{4}\right)_{2} \mathrm{SO}_{4}, 0.38 \mathrm{~g} \mathrm{KH}_{2} \mathrm{PO}_{4}, 0.39 \mathrm{~g} \mathrm{~K}_{2} \mathrm{HPO}_{4}$, and $1 \mathrm{~mL}$ basal salt solution [27]) agar plates. A series of 5-fold dilutions were prepared using the carbon-free medium. Three agar plates were used per one of the serial dilutions. The agar plates were cultivated for approximately 7 days at $30{ }^{\circ} \mathrm{C}$ in the dark, and the number of colonies was counted. The percent survival was calculated as a percentage of colony forming units (CFUs) without exposure to $\mathrm{NaCl}$ stress.

\subsection{Microscopic Analysis of Cells}

Phase-contrast images of cells were captured with optical microscope (Axio Imager 2, Carl Zeiss, Oberkochen, Germany) equipped with a camera DP73 (Olympus, Tokyo, Japan). The length of the long axis of rod-shaped cells was measured with cellSens imaging software (cellSens standard, Olympus). The length of 150 cells were measured for each sample with three replications. 


\section{Results}

\subsection{Cellular ATP Contents}

The exponentially growing cells and the growth-terminated cells due to carbon depletion (i.e., the starvation-initiated cells) were prepared as described above. The starvation-initiated cells were incubated in the light and dark to prepare 1-d starved cells in the light and 1-d starved cells in the dark, respectively. Their colony forming unit (CFU) values were not significantly changed by the 1-d starvation ( $p>0.05$ by the Student's $t$-test, data not shown), as previously shown. As summarized in Table 1, cellular ATP contents slightly increased from $(4.12 \pm 0.52) \times 10^{-16} \mathrm{~mol} \mathrm{CFU}^{-1}$ in the growing cells to $(6.45 \pm 0.37) \times 10^{-16} \mathrm{~mol} \mathrm{CFU}^{-1}$ in the growth-terminated cells. This was likely due to the reduction of ATP consumption caused by growth termination. ATP content significantly increased to $(12.9 \pm 0.87) \times 10^{-16}$ mol CFU ${ }^{-1}$ and decreased to $(4.06 \pm 0.45) \times 10^{-16}$ mol CFU $^{-1}$ after 1 -d anaerobic starvation in the light and the dark, respectively. As suggested previously [23,28], ATP is probably consumed to maintain viability even under carbon starvation conditions, but in the case of this bacterium ATP can be photosynthetically produced in the light. When aerobic dark conditions were applied after growth termination, the 1-d aerobic starved cells showed high ATP contents, $(7.49 \pm 0.11)$ $\times 10^{-16} \mathrm{~mol} \mathrm{CFU}^{-1}$, in contrast to the anaerobic starved cells in the dark. This probably indicates that oxygen supply allows the cells to maintain cellular ATP levels through oxidative phosphorylation using a part of cellular organic compounds as the source of electron donors.

Table 1. Cellular ATP contents.

\begin{tabular}{cccccc}
\hline & $\begin{array}{c}\text { Growing } \\
\text { Cells }\end{array}$ & $\begin{array}{c}\text { Starvation-Initiated } \\
\text { Cells }\end{array}$ & $\begin{array}{c}\text { 1-d Anaerobic } \\
\text { Starved Cells in } \\
\text { the Light }\end{array}$ & $\begin{array}{c}\text { 1-d Anaerobic } \\
\text { Starved Cells in } \\
\text { the Dark }\end{array}$ & $\begin{array}{c}\text { 1-d Aerobic } \\
\text { Starved Cells } \\
\text { in the Dark }\end{array}$ \\
\hline$\times 10^{-16} \mathrm{~mol} \mathrm{CFU}^{-1}$ & $4.12 \pm 0.52$ & $6.45 \pm 0.37$ & $12.9 \pm 0.87$ & $4.06 \pm 0.45$ & $7.49 \pm 0.11$ \\
\hline
\end{tabular}

\subsection{Salt Stress Tolerance}

Salt stress tolerance was evaluated after exposure to $2.5 \mathrm{M} \mathrm{NaCl}$ for $1 \mathrm{~h}$ (Figure 1). Upon the application of stress to the growing cells, the percent survival was $11.3 \%$. The sensitivity to the salt stress was nearly unchanged in the starvation-initiated cells: only less than $15 \%$ of starvation-initiated cells were tolerant. We reported previously that the starvation-initiated cells of R. palustris CGA009 were resistant to $10-\mathrm{min}$ incubation in $2.5 \mathrm{M} \mathrm{NaCl}$ [24]. The present results indicate that the prolonged exposure to $2.5 \mathrm{M} \mathrm{NaCl}$ for $1 \mathrm{~h}$ decreased viability of the starved cells.

Although salt stress tolerance in 1-d anaerobic starved cells in the dark did not increase (the survival ratio was $16.1 \%$ ), a marked increase in the salt stress tolerance was observed in 1-d anaerobic starved cells in the light and 1-d aerobic starved cells in the dark: their percent survival were $79.7 \%$ and $98.1 \%$, respectively (Figure 1). Changes in the salt stress tolerance of starved cells in the light were determined during a 24-h incubation after growth termination (Figure 2). The percent survival did not largely change until $18 \mathrm{~h}$ of incubation, and significantly increased at $24 \mathrm{~h}$. 


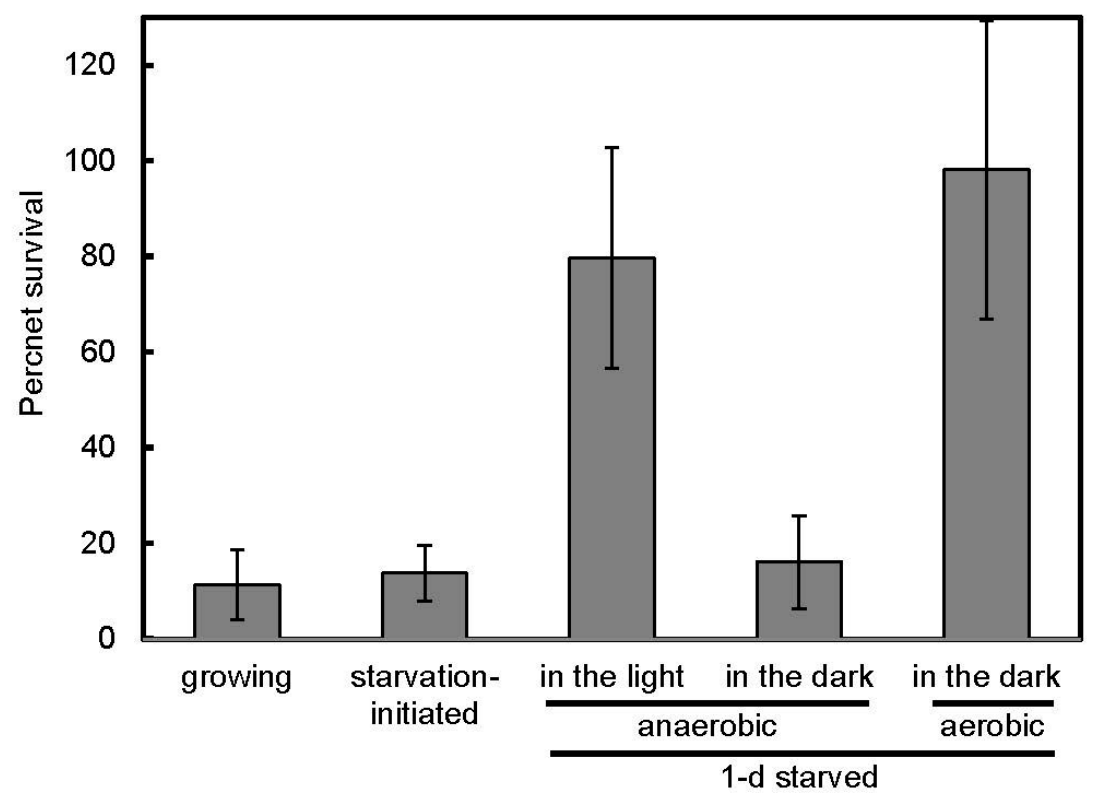

Figure 1. Survivability after exposure to salt stress. CFU values after incubation in $2.5 \mathrm{M} \mathrm{NaCl}$ for $1 \mathrm{~h}$ in the dark were determined for exponentially growing cells (growing), starvation-initiated cells (starvation-initiated), 1-d anaerobic starved cells in the light, 1-d anaerobic starved cells in the dark, and 1-d aerobic starved cells in the dark. The percent survival was calculated as a percentage of CFUs after incubation without $\mathrm{NaCl}$. Error bars indicate standard deviation of three or four biological replicates.

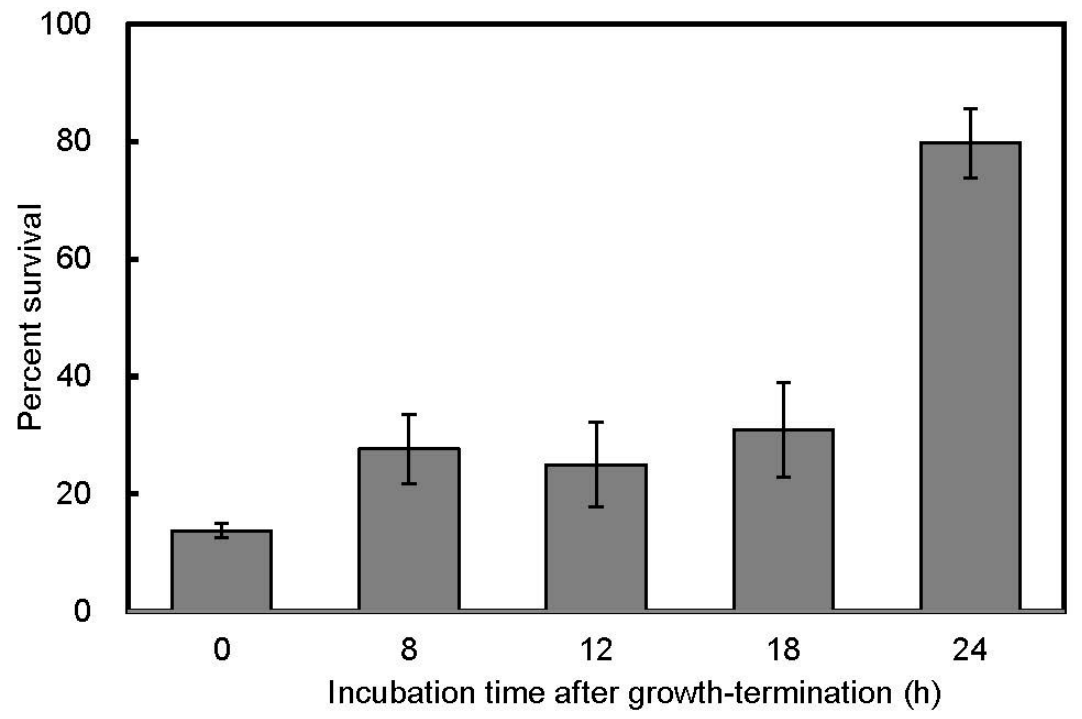

Figure 2. Changes in salt stress tolerance of starved cells in the light. As shown in Figure 1, the percent survival after exposure to $2.5 \mathrm{M} \mathrm{NaCl}$ stress were determined for starvation-initiated cells (i.e., $0 \mathrm{~h}$ starved cells) and anaerobic starved cells incubated for 8 h, 12 h, 18 h, and $24 \mathrm{~h}$ in the light. Error bars indicate standard deviation of three biological replicates.

\subsection{Cell Size}

The cell length distribution was measured in the exponentially growing cells, starvation-initiated cells, 1-d anaerobic starved cells in the light, 1-d anaerobic starved cells in the dark, and 1-d aerobic starved cells in the dark with phase-contrast microscopy (Figure 3). In the growing culture, there were two peaks in the distribution of cell length: the shorter cells seem to be cells just after cell division, 
and the longer cells could be elongated cells before cell division. In the starvation-initiated cultures, more than $60 \%$ of the cells had cell lengths in the range from 2.2 to $3.4 \mu \mathrm{m}$. Cell length after 1 -d anaerobic starvation in the dark was not markedly changed as compared to starvation initiation. However, 1-d anaerobic starvation in the light shortened the cell length, i.e., most cells in the 1-d anaerobic starved culture in the light had lengths of 1.4-2.6 $\mu \mathrm{m}(72 \%)$. Similarly, shorter cells appeared after 1-d aerobic starvation in the dark.

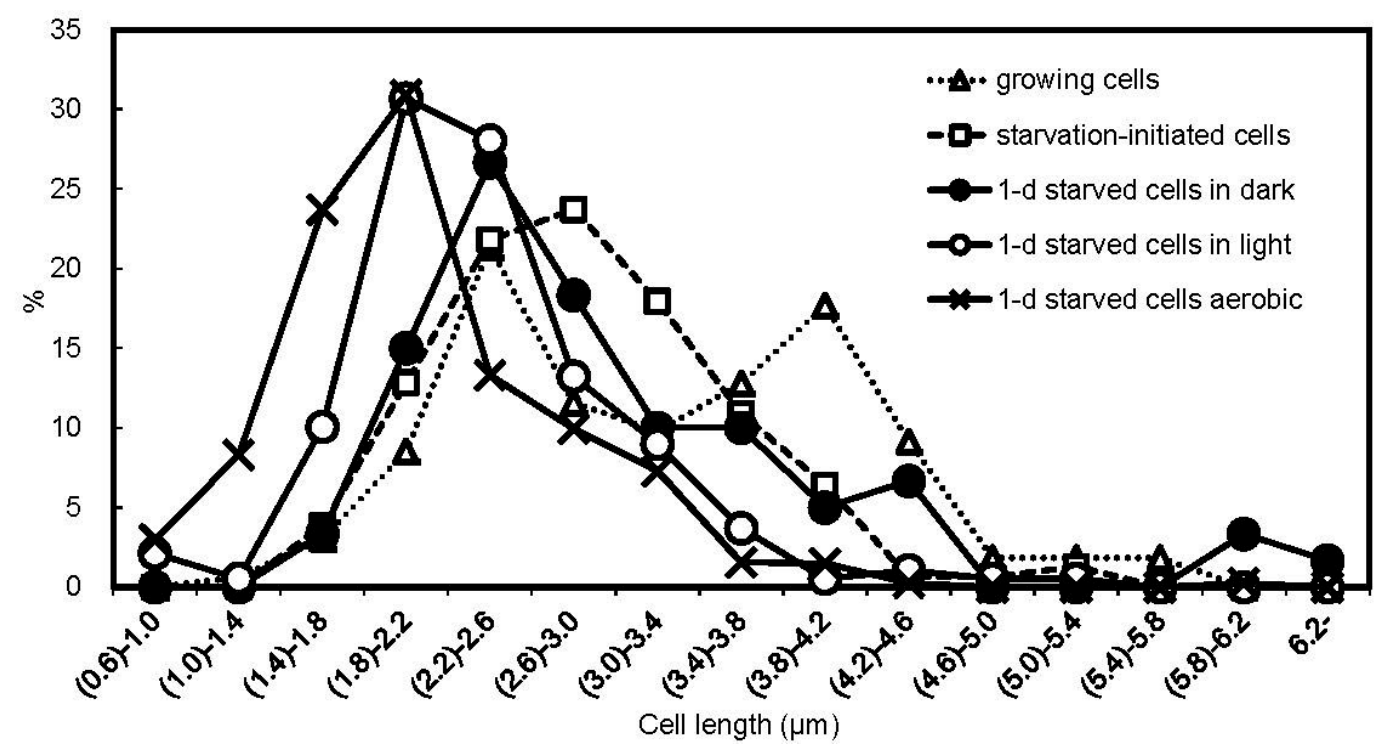

Figure 3. Frequency distribution of cell length. The length of the long axis of rod-shaped cells was measured for exponentially growing cells, starvation-initiated cells, 1-d anaerobic starved cells in the light, 1-d anaerobic starved cells in the dark, and 1-d aerobic starved cells in the dark. The frequency of the cell lengths is represented as a percentage of the total cells measured. The lengths of 150 cells were measured for each sample with three replications. The horizontal axis indicates cell length $(\mu \mathrm{m})$, and the percentages of cells with lengths in the range in total cells measured are plotted, e.g., (0.6)-1.0 indicates a range from longer than $0.6 \mu \mathrm{m}$ to $1.0 \mu \mathrm{m}$.

\section{Discussion}

In this study, the carbon-starved cells of $R$. palustris CGA009 were incubated for $24 \mathrm{~h}$ (1) anaerobically in the light (photosynthetic conditions); (2) aerobically in the dark (respiratory conditions); or (3) anaerobically in the dark in the absence of a terminal electron acceptor. We found that cellular ATP levels in this bacterium were decreased by 1-d starvation in the dark, but the ATP levels in the starved cells in the light and the aerobic starved cells were increased (Table 1). The latter two types of starved cells showed high tolerance to the salt stress (Figure 1). In the salt-tolerant cells, the cell length was markedly shortened (Figure 3), supporting the rearrangement of cellular components during the starved incubation of cells with the energy supply. It has been suggested that cell size reduction is an adaptation response to unfavorable conditions [29] and that also seems to be the case in this study. The large increase in the salt tolerance under the conditions of energy supply may be related to changes in cells in preparation for possibly forthcoming large stresses in natural environments.

Cellular ATP can be used to drive ion efflux pumps to maintain cellular osmolality $[30,31]$. However, it is unlikely that ATP-powered transporters largely contributed to the resistance to the salt stress in the starved cells of R. palustris, since more than $75 \%$ of total cellular ATP in 1-d starved cells disappeared within 10 min when the cells were exposed to $\mathrm{NaCl}$, and the ATP contents after the decrease were less than those in the sensitive cells (data not shown). Oren reported that cellular ATP leaks from cells under hyperosmotic pressure [30]. During the starvation period, it is likely 
that ATP was used to make cells tolerant against the stress and the rearrangement needed sufficient time as indicated in Figure 2. It has been suggested that tolerance to high osmolality is increased by reconstruction of cytoplasmic membrane [32-34] or cell wall [35]. These changes in the membrane or cell wall could be accompanied by the reduction of cell size, which was observed in the tolerant cells (Figure 3). High accumulation of a compatible solute such as trehalose and glycine betaine in cytoplasm does not seem to occur under the conditions where available carbon sources are limited [36,37].

Our results strongly indicate that cellular energy influences starvation responses. ATP production through photosynthesis and aerobic respiration probably supports the adaptive changes. Carbonstarvation-induced changes have been reported for several species of non-photosynthetic aerobic bacteria [3], and most of those studies applied aerobic conditions to starved cells [11,16,38-40]. Similar effects of anaerobic illumination and oxygen supply on the salt tolerance in this study indicate that the energy supply is a major factor in rearranging the non-growing cells for stress tolerance. Aerobic respiration may also be helpful for the starvation responses in various bacteria, as shown in this study. These could provide an important aspect with respect to the survivability of bacteria in natural environments. Bacteria under non-growing states appear to actively respond to environments, and manage the synthesis and utilization of their cellular energy to not only to maintain their viability under the given conditions but also to prepare the cells for further environmental changes.

Supplementary Materials: The following are available online at http:/ /www.mdpi.com/2076-2607/6/1/4/s1, Figure S1: Phototrophic growth of R. palustris CGA009 in the carbon-limited medium.

Acknowledgments: We thank Nina R. Salama (Fred Hutchinson Cancer Research Center) for valuable discussion and Shigeki Ehira (Tokyo Metropolitan University) for helpful comments on the manuscript. We are grateful to Donald Anderson for critical reading of the manuscript and English editing.

Author Contributions: S.W., N.K., K.M., and S.H. designed the study. S.W. and N.K. performed the experiments and S.W. analyzed the data. S.W. and S.H. drafted the manuscript. All authors wrote, revised, and approved the final version.

Conflicts of Interest: The authors declare no conflict of interest.

\section{References}

1. Roszak, D.B.; Colwell, R.R. Survival strategies of bacteria in the natural environment. Microbiol. Rev. 1987, 51, 365-379. [PubMed]

2. Kjelleberg, S.; Albertson, N.; Flärdh, K.; Holmquist, L.; Jouper-Jaan, A.; Marouga, R.; Ostling, J.; Svenblad, B.; Weichart, D. How do non-differentiating bacteria adapt to starvation? Antonie Leeuwenhoek 1993, 63, $333-341$. [CrossRef] [PubMed]

3. Rangel, D.E.N. Stress induced cross-protection against environmental challenges on prokaryotic and eukaryotic microbes. World J. Microbiol. Biotechnol. 2011, 27, 1281-1296. [CrossRef] [PubMed]

4. Rittershaus, E.S.C.; Baek, S.-H.; Sassetti, C.M. The Normalcy of dormancy: Common themes in microbial quiescence. Cell Host Microbe 2013, 13, 643-651. [CrossRef] [PubMed]

5. Dietrich, J.; Roy, S.; Rosenkrands, I.; Lindenstrøm, T.; Filskov, J.; Rasmussen, E.M.; Cassidy, J.; Andersen, P. Differential influence of nutrient-starved Mycobacterium tuberculosis on adaptive immunity results in progressive tuberculosis disease and pathology. Infect. Immun. 2015, 83, 4731-4739. [CrossRef] [PubMed]

6. Ayrapetyan, M.; Williams, T.C.; Oliver, J.D. Bridging the gap between viable but non-culturable and antibiotic persistent bacteria. Trends Microbiol. 2015, 23, 7-13. [CrossRef] [PubMed]

7. Li, L.; Mendis, N.; Trigui, H.; Oliver, J.D.; Faucher, S.P. The importance of the viable but non-culturable state in human bacterial pathogens. Front. Microbiol. 2014, 5, 258. [CrossRef] [PubMed]

8. Nguyen, D.; Joshi-Datar, A.; Lepine, F.; Bauerle, E.; Olakanmi, O.; Beer, K.; McKay, G.; Siehnel, R.; Schafhauser, J.; Wang, Y.; et al. Active starvation responses mediate antibiotic tolerance in biofilms and nutrient-limited bacteria. Science 2011, 334, 982-986. [CrossRef] [PubMed]

9. Haruta, S.; Kanno, N. Survivability of microbes in natural environments and their ecological impacts. Microbes Environ. 2015, 30, 123-125. [CrossRef] [PubMed]

10. Chen, S.-Y.; Jane, W.-N.; Chen, Y.-S.; Wong, H. Morphological changes of Vibrio parahaemolyticus under cold and starvation stresses. Int. J. Food Microbiol. 2009, 129, 157-165. [CrossRef] [PubMed] 
11. Givskov, M.; Eberl, L.; Møller, S.; Poulsen, L.K.; Molin, S. Responses to nutrient starvation in Pseudomonas putida KT2442: Analysis of general cross-protection, cell shape, and macromolecular content. J. Bacteriol. 1994, 176, 7-14. [CrossRef] [PubMed]

12. Kaberdin, V.R.; Montánchez, I.; Parada, C.; Orruño, M.; Arana, I.; Barcina, I. Unveiling the metabolic pathways associated with the adaptive reduction of cell size during Vibrio harveyi persistence in seawater microcosms. Microb. Ecol. 2015, 70, 689-700. [CrossRef] [PubMed]

13. Lappin-Scott, H.M.; Costerton, J.W. Starvation and penetration of bacteria in soils and rocks. Experientia 1990, 46, 807-812. [CrossRef]

14. Morita, R.Y. Bacteria in Oligotrophic Environments; Chapman \& Hall: London, UK, 1997.

15. Petrova, O.; Gorshkov, V.; Daminova, A.; Ageeva, M.; Moleleki, L.N.; Gogolev, Y. Stress response in Pectobacterium atrosepticum SCRI1043 under starvation conditions: Adaptive reactions at a low population density. Res. Microbiol. 2014, 165, 119-127. [CrossRef] [PubMed]

16. Thorne, S.H.; Williams, H.D. Adaptation to nutrient starvation in Rhizobium leguminosarum bv. phaseoli: Analysis of survival, stress resistance, and changes in macromolecular synthesis during entry to and exit from stationary phase. J. Bacteriol. 1997, 179, 6894-6901. [CrossRef] [PubMed]

17. Wu, M.-L.; Gengenbacher, M.; Dick, T. Mild nutrient starvation triggers the development of a small-cell survival morphotype in Mycobacteria. Front. Microbiol. 2016, 7. [CrossRef] [PubMed]

18. Pittman, J.; Kline, L.; Kenyon, W. Carbon-starvation induces cross-resistance to thermal, acid, and oxidative stress in Serratia marcescens. Microorganisms 2015, 3, 746-758. [CrossRef] [PubMed]

19. Allen, M.S.; Hurst, G.B.; Lu, T.-Y.S.; Perry, L.M.; Pan, C.; Lankford, P.K.; Pelletier, D.A. Rhodopseudomonas palustris CGA010 proteome implicates extracytoplasmic function sigma factor in stress response. J. Proteome Res. 2015, 14, 2158-2168. [CrossRef] [PubMed]

20. Francez-Charlot, A.; Kaczmarczyk, A.; Fischer, H.-M.; Vorholt, J.A. The general stress response in Alphaproteobacteria. Trends Microbiol. 2015, 23, 164-171. [CrossRef] [PubMed]

21. Landini, P.; Egli, T.; Wolf, J.; Lacour, S. sigmaS, a major player in the response to environmental stresses in Escherichia coli: Role, regulation and mechanisms of promoter recognition. Environ. Microbiol. Rep. 2014, 6, 1-13. [CrossRef] [PubMed]

22. McKinlay, J.B.; Oda, Y.; Rühl, M.; Posto, A.L.; Sauer, U.; Harwood, C.S. Non-growing Rhodopseudomonas palustris increases the hydrogen gas yield from acetate by shifting from the glyoxylate shunt to the tricarboxylic acid cycle. J. Biol. Chem. 2014, 289, 1960-1970. [CrossRef] [PubMed]

23. Breznak, J.A.; Potrikus, C.J.; Pfennig, N.; Ensign, J.C. Viability and endogenous substrates used during starvation survival of Rhodospirillum rubrum. J. Bacteriol. 1978, 134, 381-388. [PubMed]

24. Kanno, N.; Matsuura, K.; Haruta, S. Differences in survivability under starvation conditions among four species of purple nonsulfur phototrophic bacteria. Microbes Environ. 2014, 29, 326-328. [CrossRef] [PubMed]

25. Odaa, Y.; Slagmana, S.; Meijerb, W.G.; Forneya, L.J.; Gottschala, J.C. Influence of growth rate and starvation on fluorescent in situ hybridization of Rhodopseudomonas palustris. FEMS Microbiol. Ecol. 2000, 32, 205-213. [CrossRef] [PubMed]

26. Pechter, K.B.; Gallagher, L.; Pyles, H.; Manoil, C.S.; Harwood, C.S. Essential genome of the metabolically versatile alphaproteobacterium Rhodopseudomonas palustris. J. Bacteriol. 2016, 198, 867-876. [CrossRef] [PubMed]

27. Hanada, S.; Hiraishi, A.; Shimada, K.; Matsuura, K. Chloroflexus aggregans sp. nov., a filamentous phototrophic bacterium which forms dense cell aggregates by active gliding movement. Int. J. Syst. Bacteriol. 1995, 45, 676-681. [CrossRef] [PubMed]

28. Gengenbacher, M.; Rao, S.P.S.; Pethe, K.; Dick, T. Nutrient-starved, non-replicating Mycobacterium tuberculosis requires respiration, ATP synthase and isocitrate lyase for maintenance of ATP homeostasis and viability. Microbiology 2010, 156, 81-87. [CrossRef] [PubMed]

29. Yang, D.C.; Blair, K.M.; Salama, N.R. Staying in shape: The impact of cell shape on bacterial survival in diverse environments. Microbiol. Mol. Biol. Rev. 2016, 80, 187-203. [CrossRef] [PubMed]

30. Oren, A. Bioenergetic aspects of halophilism. Microbiol. Mol. Biol. Rev. 1999, 63, 334-348. [PubMed]

31. Pastor, J.M.; Bernal, V.; Salvador, M.; Argandoña, M.; Vargas, C.; Csonka, L.; Sevilla, Á.; Iborra, J.L.; Nieto, J.J.; Cánovas, M. Role of central metabolism in the osmoadaptation of the halophilic bacterium Chromohalobacter salexigens. J. Biol. Chem. 2013, 288, 17769-17781. [CrossRef] [PubMed] 
32. Denich, T.J.; Beaudette, L.A.; Lee, H.; Trevors, J.T. Effect of selected environmental and physico-chemical factors on bacterial cytoplasmic membranes. J. Microbiol. Methods 2003, 52, 149-182. [CrossRef]

33. López, C.S.; Garda, H.A.; Rivas, E.A. The effect of osmotic stress on the biophysical behavior of the Bacillus subtilis membrane studied by dynamic and steady-state fluorescence anisotropy. Arch. Biochem. Biophys. 2002, 408, 220-228. [CrossRef]

34. Tymczyszyn, E.E.; Gómez-Zavaglia, A.; Disalvo, E.A. Influence of the growth at high osmolality on the lipid composition, water permeability and osmotic response of Lactobacillus bulgaricus. Arch. Biochem. Biophys. 2005, 443, 66-73. [CrossRef] [PubMed]

35. Lam, H.; Oh, D.-C.; Cava, F.; Takacs, C.N.; Clardy, J.; de Pedro, M.A.; Waldor, M.K. D-amino acids govern stationary phase cell wall remodeling in bacteria. Science 2009, 325, 1552-1555. [CrossRef] [PubMed]

36. Welsh, D.T. Ecological significance of compatible solute accumulation by micro-organisms: From single cells to global climate. FEMS Microbiol. Rev. 2000, 24, 263-290. [CrossRef] [PubMed]

37. Sleator, R.D.; Hill, C. Bacterial osmoadaptation: The role of osmolytes in bacterial stress and virulence. FEMS Microbiol. Rev. 2002, 26, 49-71. [CrossRef] [PubMed]

38. Klančnik, A.; Botteldoorn, N.; Herman, L.; Možina, S.S. Survival and stress induced expression of groEL and rpoD of Campylobacter jejuni from different growth phases. Int. J. Food Microbiol. 2006, 112, 200-207. [CrossRef] [PubMed]

39. Rockabrand, D.; Arthur, T.; Korinek, G.; Livers, K.; Blum, P. An essential role for the Escherichia coli DnaK protein in starvation-induced thermotolerance, $\mathrm{H}_{2} \mathrm{O}_{2}$ resistance, and reductive division. J. Bacteriol. 1995, 177, 3695-3703. [CrossRef] [PubMed]

40. Van Overbeek, L.S.; Eberl, L.; Givskov, M.; Molin, S.; van Elsas, J.D. Survival of, and induced stress resistance in, carbon-starved Pseudomonas fluorescens cells residing in soil. Appl. Environ. Microbiol. 1995, 61, 4202-4208. [PubMed]

(C) 2018 by the authors. Licensee MDPI, Basel, Switzerland. This article is an open access article distributed under the terms and conditions of the Creative Commons Attribution (CC BY) license (http:/ / creativecommons.org/licenses/by/4.0/). 